Оксана КОВАЛЕНКО, orcid.org/0000-0003-2675-0224 викладач кафедри англійської мови

факультету філологіі Чорноморського національного університету імені Петра Могили (Миколаїв, Україна) anglu4itel@gmail.com

Свгенія ПОСТИКІНА, orcid.org/0000-0001-8431-5859 викладач кафедри англійської мови факультету філологї Чорноморського начіонального університету імені Петра Могили (Миколаїв, Україна) frozen_13@bk.ru

\title{
ТЕСТУВАННЯ ЯК ЗАСІБ КОНТРОЛЮ ТА РОЗВИТКУ КОМПЕТЕНЦЙ СТУДЕНТІВ СПЕЦІАЛЬНОСТІ «ГЕОДЕЗІЯ»
}

У статті зазначено, щуо в сучасному світі в умовах інтеграції гостро постала проблема якості освіти, а саме мовної комунікації.

Ми шукаємо різні методи та технології оцінювання, які будуть співвідноситися з міжнародними стандартами. Щоб Україна входила в число технічно, економічно та культурно розвинутих країн світу, насамперед необхідно модернізувати вітчизняну освіту.

У проиесі модернізації процесу освіти відбувається $і$ зміна иільових настанов, змісту і технології навчання. Використання сучасних інформаційних технологій забезпечує інтенсифікацію й актуалізацію навчально-виховного проиесу. Стрімка інформатизація сучасного суспільства висуває на передній план проблеми розвитку ефективних методик навчання, а також удосконалення системи автоматизованого контролю та вимірювання рівня знань. Швидка і якісна оцінка знань студентів є актуальною проблемою освітнього процесу.

Головне завдання, щчо стоїть перед всіма викладачами іноземних мов, - навчити своїх студентів якомога влучніше й ефективніше володіти іноземною мовою для готовності спілкування будь-якого формату і розуміння співрозмовника в різних життевих ситуаціях.

Для будь-якої системи освіти найважливішими залишаються об'єктивний контроль якості знань $і$ на цій основі побудова результативних алгоритмів навчання. Одним із сучасних видів такого контролю виступає тестування.

Однією з головних иілей, щуо постають під час реформувань в освіті, є забезпечення належного, грамотного та модернізованого рівня знань у галузі іноземних мов.

Головним завданням сучасних викладачів є не тільки подання мовного матеріалу, а забезпечення мовної комунікативності студентів, здатності застосовувати набуті знання на практиці в умовах будь-якого спілкування.

Поняття контролю й очінювання студентів є невід 'ємними складовими частинами успішної освіти в усьому світі, важливим чинником у проиесі навчання будь-якого навчального предмета, іноземної мови також.

Поняття контролю має декілька значень, серед яких перевірка знань та вмінь чи спостереження за будьякою навчальною діяльністю.

Ключові слова: тест, тестування, відкритий $і$ закритий типи питання, діагностика, рівень знань іноземної мови, аудіювання, усне висловлювання, аспекти вивчення іноземної мови, форми, методи, контроль. 
Oksana KOVALENKO, orcid.org/0000-0001-8431-5859

Lecturer at the English Language Department of the Faculty of Philology Petro Mohyla Black Sea National University (Mykolaiv,Ukraine)anglu4itel@gmail.com

Yevheniya POSTYKINA, orcid.org/0000-0003-2675-0224

Lecturer at the English Language Department of the Faculty of Philology

Petro Mohyla Black Sea National University (Mykolaiv,_Ukraine)frozen_13@bk.ru

\section{TESTING AS A MEANS OF “GEODESY" STUDENTS COMPETENCIES' CONTROL AND DEVELOPMENT}

This article describes the problem of quality of education, language communication is denoted in the modern world in the conditions of integration.

We are looking for different assessment methods and technologies that will comply with international standards. In order for Ukraine to become one of the technically, economically and culturally developed countries of the world, first of all it is necessary to modernize domestic education.

In the course of modernization of the educational process there is a change in the target settings, content and technology of education. The use of modern information technologies provides intensification and actualization of the educational process. Rapid informatization of modern society brings to the fore the problem of developing effective teaching methods, as well as improving the system of automated control and measurement of knowledge. Fast and high-quality assessment of students' knowledge is an urgent problem of the educational process.

The main goal of all teachers of foreign languages is to teach their students as accurately and effectively as possible to speak a foreign language to be ready to communicate in any format and understand the interlocutor in different life situations.

For any education system, the most important are objective quality control of knowledge and on this basis the construction of effective learning algorithms. One of the modern types of such control is testing.

One of the main goals of education reforms is to ensure an appropriate, competent and modernized level of knowledge in foreign languages.

The main task of modern teachers is not only the presentation of language material, but to ensure the linguistic communicativeness of students, the ability to apply the acquired knowledge in practice in any communication.

The concepts of monitoring and evaluation of students are an integral part of successful education around the world, they are an important factor in the learning process in any subject, including foreign languages.

The concept of control has several meanings, including testing knowledge and skills or observing any educational activity.

Key words: test, testing, open and closed types of questions, diagnostics, level of knowledge of foreign language, listening, oral expression, aspects of learning foreign language, forms, methods, control.

Постановка проблеми. Розвиток якості освіти в Україні проводиться шляхом зовнішнього незалежного оцінювання досягнень випускників середніх загальноосвітніх навчальних закладів та студентів-бакалаврів, за результатами якого проводяться їх державна підсумкова атестація та конкурсний відбір для навчання у вищих навчальних закладах та магістратурі. Такі умови фінального оцінювання вимагають від учителів та викладачів використання більш ефективних прийомів та методів контролю й оцінки знань, умінь та навичок студентів. Серед таких ефективних прийомів можна виділити тестування, що означає актуальність обраного наукового дослідження.

Аналіз досліджень. Звичайно, сучасний процес навчання іноземної мови неможливий без тестування. Важливо чітко уявляти завдання, можливості та мету даної процедури. Якісне навчання іноземних мов передбачає не тільки використання хороших підручників i автентичних матеріалів, роботу досвідченого викладача, але і своєчасне відстеження прогресу у вивченні предмета для грамотного планування або більш точного підстроювання процесу навчання, перевірку залишкових знань і оцінку кінцевого результату.

Німецькі методисти та викладачі німецької мови як іноземної Г. фон дер Хандт, А. Шнайдер, Г. Хельбіг та інші розрізняють різні види тестів у сфері їхньої діяльності.

Тестовий контроль $\epsilon$ ефективною формою контролю, що забезпечує ефективну реалізацію всіх його функцій у процесі навчання будь-якої іноземної мови за професійним спрямуванням. 
Мета статті - розглянути ефективність тестового контролю, особливості його використання в навчанні іноземної мови за професійним спрямуванням.

Ми хочемо проаналізувати плюси і мінуси тестування як методу контролю знань; визначити його форми й особливості на заняттях іноземної мови за професійним спрямуванням.

Виклад основного матеріалу. Насамперед необхідно зазначити, що в сучасному світі психологічним і соціальним запитом студентів $€$ мовна комунікація, тому що вивчення іноземної мови за професійним спрямуванням є досить складним процесом, що потребує індивідуального підходу до кожного, більше часу для засвоєння матеріалу.

У студентів початкових і старших курсів 3'являються деякі психологічні особливості, що відрізняють навчання минулих років. Мислення студента спеціальності «Геодезія» набуває емоційного характеру, а інтелектуальна діяльність пов'язана 3 його самовизначенням i бажанням розвиватися у професії. Психологічні особливості розвитку студента проявляються в усіх аспектах його навчальної діяльності. У цей період для студента важливе не засвоєння окремих фактів чи деталей, а розуміння сутності, конкретних дій або загальної схеми діяльності (Баранова, 2002: 13).

Перед учителями постає мовленнєве завдання, а також комунікативна мотивація, яку треба забезпечити для ініціативної участі студента у спілкуванні.

На старших курсах систематизується й узагальнюється мовний досвід студентів, набутий ними на попередніх ступенях вивчення мови. Методи і види навчальної діяльності все більше набувають форм, наближених до реальних умов спілкування. Широко використовуються творчі, проєктні, групові, інтерактивні форми роботи студентів. Зміст освіти диференціюється відповідно до профілю навчання (Гальскова, 2000: 50).

Отже, головними аспектами в навчанні іноземної мови за професійним спрямуванням $\epsilon$ усвідомлення психологічних особливостей віку та формування і розвиток у студентів мовної компетентності як головної умови подолання мовленнєвого бар'єра.

Контроль допомагає вчителю визначити:

1) ступінь засвоєння матеріалу;

2) прогалини у знаннях з окремих тем;

3) оцінити свою роботу, знайти в ній недоліки і виправити;

4) своєчасно звернути увагу на неправильне розуміння матеріалу;

5) перевірити вміння застосовувати набуті знання;
6) перевірити повноту знань тощо.

Зазначимо такі види контролю на заняттях іноземної мови за професійним спрямуванням, як:

- контроль говоріння (перевіряються навички опанування мовленнєвих механізмів, правильність і змістовність висловлювань);

- контроль читання та письма (читання перевіряється в розумінні тексту і техніки читання в голос, а письмо - правильним написанням диктанту тощо);

- контроль аудіювання (контроль розуміння прослуханого тексту).

Щоби перевірити ефективність викладання, засвоєння матеріалу, незрозумілі для студентів теми, рівень їхньої освіти, у всьому світі використовують різні методи контролю знань і оцінювання.

Реалізація контролю в навчанні іноземної мови за професійним спрямуванням проводиться різними методами, але тестування є більш доречним методом перевірки студентських знань. Тест також $є$ хорошим елементом для підкріплення набутих знань (Гривко, 2015: 134).

Розрізняють такі види контролю вивчення іноземної мови за професійним спрямуванням умзакладі вищої освіти:

1. Попередній контроль, коли перевіряється вихідний рівень підготовки, тобто ступінь засвоєння програми $з$ іноземної мови за професійним спрямуванням. Поточний контроль, тобто контроль умінь і навичок, набутих після проходження деякої частини лексичного і граматичного матеріалу. Він здійснюється періодично протягом усього процесу навчання у виші.

2. Поточний або підсумковий контроль, який зазвичай проводиться після вивчення розділу підручника. Результати такого контролю дозволяють коригувати подальший перебіг навчального процесу.

3. Підсумковий контроль, який проводиться зазвичай після завершення навчання протягом семестру, у період екзаменів.

Усний контроль, або опитування, є найбільш поширеною формою контролю знань, умінь і навичок студентів. Під час такого опитування викладач отримує широкі можливості для вивчення індивідуальних особливостей засвоєння студентом навчального матеріалу, виявлення найбільш важливих для кожного виду мовленнєвої діяльності якостей: мовної реакції, мовної автоматизації, ситуативності мовлення (Логвина, 2012: 45).

Зазвичай контроль проводиться у вигляді бесіди, під час якої викладач ставить питання і чекає на відповідь учня. Буває він і у вигляді розповіді або 
повідомлення учня на певну тему, а також у вигляді пояснення якої-небудь події або явища.

Щоб індивідуальні опитування не призводили до тривалої пасивності всієї групи студентів, питання повинні бути чіткими і конкретними, які охоплюють основний досліджуваний матеріал.

Тривалість індивідуального опитування не повинна перевищувати чотирьох хвилин. Фронтальне опитування зазвичай пов'язане з повторенням раніше пройденого або нещодавно пройденого матеріалу. Питання і відповіді в разі такого опитування мають бути короткими, щоб залучити до роботи всіх студентів групи. Специфіка письмового контролю знань, умінь і навичок з іноземної мови за професійним спрямуванням полягає в його економічності - перевіркою водночас охоплені всі студенти (Олейникова, 2010:15).

За такого контролю в письмових роботах студентів легше кваліфікувати помилки.

Тестовий контроль, на відміну від традиційного опитування та письмового контролю, завжди припускає деяке вимірювання. Тому оцінка, яка виставляється за підсумками тестування, вирізняється об'єктивністю, незалежністю від можливого суб'єктивізму викладача, коли буде виставлена оцінка, деякою мірою заснована на враженні того, хто навчає, його особистих симпатіях чи антипатіях стосовно студента.

Такий контроль може служити хорошим засобом діагностики труднощів мовного матеріалу для студентів, мірою визначення ефекту навченості, способом прогнозування успішності чи неуспішності навчання.

Контроль часто ототожнюється 3 формалізованої перевіркою або тестуванням. Однак формальний контроль (наприклад, у формі проміжного тесту або підсумкового іспиту) не єдиний його вид (Черноватий, 2013: 230).

Не менш важливий також неформальний (або поточний) контроль, який триває на занятті та під час виконання домашніх завдань. Крім того, можна використовувати тести й оцінювати те, як вони виконуються. Однак практично не використовується можливість залучення студентів до цього процесу. Самоконтроль, як показує досвід, здатний не тільки доповнити й уточнити судження вчителя про те, як відбувається навчання, а й істотно вплинути на ставлення студентів до навчання і формального контролю.

Повернемося до формального підходу та зазначимо, що тести й іспити, які реалізують формальний контроль, призначаються, 3 одного боку, для оцінки того, як ті, кого навчають, уміють виконувати специфічні комунікативні завдання, тобто наскільки вони володіють мовою, що вивчається, а 3 іншого - для оцінки того, наскільки навчальний курс відповідає цілям, які ставилися під час його розроблення.

С чотири основні типи тестів, що реалізують формальний контроль, і особливе призначення кожного з них. Саме їхнє особливе призначення (або головна функція) дозволяє розрізнити один тип тесту від іншого. Однак кожен із них може мати й інші завдання. Так, перші три типи тестів можуть бути спрямовані на виявлення слабких сторін студентів.

Власне діагностичні тести варто застосовувати дуже обережно. Необхідно прагнути до того, щоб такі тести не чинили негативного впливу на навчальний процес, бо, як показує практика, вони нерідко створюють атмосферу напруженості, а часом і недовіри. Зупинимося докладніше на перших трьох типах тестів, що дозволяють здійснювати формальний контроль (Голуб, 2008: 170).

1. Установчі тести проводяться перед початком навчання i виконують три функції, як-от: a) визначення рівня володіння іноземною мовою учнями; б) діагностування вад володіння мовою (результати тесту варто розглядати з конструктивних позицій, а саме використовувати, наприклад, для визначення характеру і змісту курсу іноземної мови за професійним спрямуванням); в) розподіл студентів по групах. Варто зазначити, що тест це не єдиний засіб діагностування потреб студентів у вивченні іноземної мови за професійним спрямуванням, хоча він може надати інформацію не тільки про те, чого учневі бракує, але і який потенціал може бути задіяний.

2. Тести успішності вивчення курсу іноземної мови за професійним спрямуванням знайомі вчителеві найкраще, оскільки вони будуються на досліджуваному матеріалі, допомагають здійснювати проміжний контроль, що забезпечує зворотний зв'язок, такий необхідний для оптимізації навчального процесу та вдосконалення курсу.

3. Тести володіння мовою покликані реалізувати підсумковий контроль. Це зазвичай співвіднесені із критерієм тести. Їхня мета полягає в тому, щоб показати, наскільки учні навчилися вирішувати комунікативні завдання мовою, що вивчається, що необхідно їм для продовження навчання на більш високому рівні. Яскравим прикладом таких тестів $є$ іспит IELTS (International English Language Testing System), що оцінює здатність іноземних студентів навчатися у виші в англомовному середовищі.

Щоби вчасно виявляти незрозумілі для студентів теми, підсумовувати їх, перевіряти закрі- 
плення матеріалу й оцінювати освітню діяльність, було створено особливі методи контролю, серед яких тестування (Олейникова, 2010: 18).

Тестування у процесі навчання англійської мови $€$ важливим показником щодо виявлення рівня досягнень студентів, їхніх здібностей, проблем у розумінні будь-яких тем тощо.

У навчанні іноземних мов найчастіше застосовується саме лінгводидактичне тестування.

Лінгводидактичний тест - це підготовлений відповідно до певних вимог комплекс завдань, які дозволяють виявити в учасників тестування рівень їхньої лінгвістичної і комунікативної компетенції, оцінити результати тестування за заздалегідь виведеними критеріями.

Серед основних показників якості лінгводидактичного тесту такі:

1. Валідність - характеристика тесту, яка показує, що саме визначає тест, наскільки ефективно він це робить. Валідність тесту означає його придатність для визначення рівня володіння певними іншомовними мовленнєвими навичками і вміннями.

2. Надійність - це необхідна умова валідності тесту. Надійність тесту визначається стабільністю його функції як інструмента вимірювання. Надійний тест дає приблизно однакові результати під час кожного застосування.

3. Диференційна здатність - характеристика тесту, яка вказує на здатність тесту виявляти серед студентів тих, хто встигає, і тих, хто не встигає, тобто визначати студентів із достатнім і недостатнім рівнем володіння іномовними навичками i вміннями.

4. Практичність - характеристика тесту, яка визначає:

а) доступність інструкцій тесту та змісту тестових завдань;

б) простоту організації проведення тестування в різних умовах;

в) простоту перевірки відповідей, визначення результатів і оцінки.

5. Економічність - характеристика тесту, яка передбачає мінімальні витрати часу, зусиль і коштів на підготовку тесту від планування до перевірки.

Тестування має багато типів і форм, серед яких можуть бути такі:

1. Множинний вибір. Серед багатьох варіантів вибери необхідний.
2. Послідовний вибір. Прочитай текст і послідовно постав необхідну літеру, що відповідає вказаним подіям.

3. Множинний вибір для заповнення пропуску в реченні.

4. Альтернативний вибір. Вибери речення, що відповідає поданому малюнку.

5. Перехресний вибір. Заповни пропуски в реченнях тексту, варіанти яких вказані після тексту.

6. Вільний вибір. Визнач основну ідею тексту або зроби малюнок відповідно до тексту.

Отже, головна відмінна риса тесту полягає в тому, щоб давати кількісну інформацію про якість засвоєння. Водночас він надає можливість перевірити великий об'єм вивченого матеріалу малими порціями та проаналізувати опанування матеріалу більшістю студентів.

Висновки. У підсумку можемо констатувати, що контроль як складова частина навчального процесу використовується тоді, коли потрібно встановити, як учні використовують мову, яку вивчають, наскільки вони просунулися у вивченні, або діагностувати наявні в них проблеми, забезпечити їм необхідний зворотний зв'язок.

Контроль часто пов'язаний з оцінкою різних чинників, що впливають на навчальний процес: сформульованих у програмі цілей, проєктування курсу, матеріалів, методики роботи вчителя i процедур самого контролю. Він $є$ одним 3 основних джерел інформації про те, що відбувається в навчальному процесі.

Метою контролю $є$ виявлення рівня засвоєння знаньучняминарізнихетапахнавчальногопроцесу, визначення відповідності виявленого рівня знань запланованому, використання отриманих даних для управління подальшим процесом навчання.

Контроль відрізняється від інших типів сприйняття тим, що він являє собою порівняльне сприйняття, у процесі якого дії учня зіставляються 3 певним еталоном. Те, що сприймається 3 метою контролю, називають об'єктом контролю. Це можуть бути деякі правила вимови, граматичні правила, правила читання або засвоєння лексики тощо.

Основне завдання навчання іноземної мови за професійним спрямуванням полягає у формуванні вміння висловлювати власні думки мовою, що вивчається, розуміти мову, коли нею говорять інші люди. Контролю підлягають всі аспекти мовної комунікації: аудіювання, говоріння, читання і письмо. 


\section{СПИСОК ВИКОРИСТАНИХ ДЖЕРЕЛ}

1. Баранова С. В. Актуальні питання методики викладання перекладу. Вісник Сумського державного університету. Серія «Філологічні науки». 2002. № 4 (37). С. 12-15.

2. Гальскова Н. Д. Современная методика обучения иностранным языкам. Москва : АРКТИ, 2000. 66 с.

3. Гривко А. В. Складники моніторингу для оцінювання ключової комунікативної компетентності учнів. Анотовані результати науково-дослідної роботи Інституту педагогіки Національної академії педагогічних наук України за 2015 р. Київ : Інститут педагогіки, 2015. 302 с. С. 133-135.

4. Голуб Г. Б., Коган Е. Я., Шишман И. С. Оценка уровня сформированности ключевых профессиональных компетентностей выпускников УНП : подходы и процедуры. Вопросы образования. 2008. № 2. 312 с. С. 161-185.

5. Загальноєвропейські рекомендації з мовної освіти : вивчення, викладання, оцінювання / наук. ред. укр. вид. С. Ю. Ніколаєва. Київ : Ленвіт, 2003. 273 с.

6. Кухар Л. О., Сергієнко В. П. Конструювання тестів. Курс лекцій : навчальний посібник. Луцьк, 2010.182 с.

7. Логвина И. М., Рождественская Л. Е. Инструменты формирующего оценивания в деятельности учителя-предметника : пособие для учителей. Нарва, 2012. 48 с.

8. Олейникова Е. А. Методика тестирования грамматики в процессе формирования профессиональной иноязычной коммуникативной компетенции : автореф. дис. ... канд. пед. наук: 13.00.02. Москва, 2010. 20 с.

9. Черноватий Л. М. Методика викладання перекладу як спеціальності : підручник для студентів вищих закладів освіти за спеціальністю «Переклад». Вінниця : Нова книга, 2013. 236 с.

\section{REFERENCES}

1. Baranova S. V. Aktual'ni pytannya metodyky vykladannya perekladu [Actual issues of translation teaching metholodgy]/ S. V. Baranova. Visnyk Sums’koho derzhavnoho un-tu. Seriya: Filolohichni nauky. 2002. № 4 (37). S. 12-15.

2. Hal'skova N. D. Sovremennaya metodyka obuchenyya ynostrannym yazykam [Modern metholodgy of foreign languages teaching] / N. D. Hal'skova. Moscow: ARKTY, 2000. 166 s. [in Russian]

3. Hryvko A. V. Skladnyky monitorynhu dlya otsinyuvannya klyuchovoyi komunikatyvnoyi kompetentnosti uchniv [Assessment components of the pupils' key communicative component] / A. V. Hryvko. Anotovani rezul'taty naukovo-doslidnoyi roboty Instytutu pedahohiky NAPN Ukrayiny za 2015 rik. Kyiv: Instytut pedahohiky, 2015. 302 s. S. $133-135$.

4. Holub H. B. Otsenka urovnya sformyrovannosty klyuchevykh professyonal'nykh kompetentnostey vypusknykov UNP: podkhody y protsedury [Assessment of graduators' key professional competence] / H. B. Holub, E. YA. Kohan, Y. S. Shyshman. Voprosy obrazovanyya. № 2. 2008. 312 s. S. 161-185. [in Russian]

5. Zahal'noyevropeys'ki Rekomendatsiyi z movnoyi osvity: vyvchennya, vykladannya, otsinyuvannya [General European Language Education Recommendation: studying, teaching, assessment]/ nauk. red. ukr. vydannya d-ra ped. nauk, prof. S. Yu. Nikolayeva. Kyiv: Lenvit, 2003. 273 s.

6. Konstruyuvannya testiv. Kurs lektsiy: navch. posib. [Test construction. Lection Course] / L. O. Kukhar, V. P. Serhiyenko. Luts'k, $2010.182 \mathrm{~s}$.

7. Lohvyna Y. Ynstrumenty formyruyushcheho otsenyvanyya v deyatel'nosty uchytelya-predmetnyka: posobye dlya uchyteley [Instruments of assessment in the subject-teaching: Book for teachers] / Yryna Lohvyna, Lyudmyla Rozhdestvenskaya. Narva, 2012. 48 s. [in Russian]

8. Oleynykova E. A. Metodyka testyrovanyya hrammatyky v protsesse formyrovanyya professyonal'noy ynoyazychnoy kommunykatyvnoy kompetentsyy: avtoref. dys. ... kand. ped. nauk: 13.00 .02 [Grammar testing methology in the process of foreign professional communicative competence formation] / Oleynykova Elena Aleksandrovna; [HOUVPO "Orlovskyy hosudarstvennyy unyversytet"] Moscow, 2010. 20 s. [in Russian]

9. Chernovatyy L. M. Metodyka vykladannya perekladu yak spetsial'nosti: pidruchnyk dlya stud. vyshchykh zakl. Osvity za spetsial'nistyu "Pereklad" [Methology of teaching the translation for professional purpose] / L. M. Chernovatyy. Vinnytsya: Nova knyha, 2013. 236 s. 